\title{
A novel soil manganese mechanism drives plant species loss with increased nitrogen deposition in a temperate steppe
}

\author{
Qiuying Tian,,${ }^{1,2}$ Nana Liu, ${ }^{1,3}$ Wenming Bai, ${ }^{1}$ Linghao Li, ${ }^{1}$ Jiquan Chen,,${ }^{4,5}$ Peter B. Reich,,${ }^{6,7}$ Qiang Yu,,${ }^{8,9}$ \\ Dali Guo, ${ }^{10}$ Melinda D. Smith, ${ }^{9}$ Alan K. Knapp, ${ }^{9}$ Weixin Cheng, ${ }^{8,11}$ Peng Lu, ${ }^{1}$ Yan GaO, ${ }^{1}$ An Yang, ${ }^{1}$ \\ Tianzuo Wang, ${ }^{1}$ Xin Li, ${ }^{1}$ Zhengwen Wang,${ }^{8}$ Yibing Ma, ${ }^{12}$ Xingguo Han ${ }^{1,8}$ and Wen-Hao Zhang ${ }^{1,2,13}$ \\ ${ }^{1}$ State Key Laboratory of Vegetation and Environmental Change, Institute of Botany, Chinese Academy of Sciences, \\ Beijing 100093, China \\ ${ }^{2}$ Research Network of Global Change Biology, Beijing Institutes of Life Science, Chinese Academy of Sciences, \\ Beijing 100101, China \\ ${ }^{3}$ University of Chinese Academy of Sciences, Beijing 100049, China \\ ${ }^{4}$ International Center for Ecology, Meteorology, and Environment (IceMe), Nanjing 210044, China \\ ${ }^{5}$ CGCEO/Geography, Michigan State University, East Lansing, Michigan 48823, USA \\ ${ }^{6}$ Department of Forest Resources, University of Minnesota, St. Paul, Minnesota 55108, USA \\ ${ }^{7}$ Hawkesbury Institute for the Environment, University of Western Sydney, Penrith, New South Wales 2753, Australia \\ ${ }^{8}$ State Key Laboratory of Forest and Soil Ecology, Institute of Applied Ecology, Chinese Academy of Sciences, \\ Shenyang 110164, China \\ ${ }^{9}$ Department of Biology and Graduate Degree Program in Ecology, Colorado State University, Fort Collins, Colorado 80523, USA \\ ${ }^{10}$ Key Laboratory of Ecosystem Network Observation and Modeling, Synthesis Research Center of Chinese Ecosystem Research \\ Network, Institute of Geographic Sciences and Natural Resources Research, Chinese Academy of Sciences, Beijing 100101, China \\ ${ }^{11}$ Environmental Studies, University of California, Santa Cruz, California 95064, USA \\ ${ }^{12}$ National Soil Fertility and Fertilizer Effects Long-term Monitoring Network, Institute of Agricultural Resources and Regional \\ Planning, Chinese Academy of Agricultural Sciences, Beijing 100081, China
}

\begin{abstract}
Loss of plant diversity with increased anthropogenic nitrogen (N) deposition in grasslands has occurred globally. In most cases, competitive exclusion driven by preemption of light or space is invoked as a key mechanism. Here, we provide evidence from a 9-yr N-addition experiment for an alternative mechanism: differential sensitivity of forbs and grasses to increased soil manganese $(\mathrm{Mn})$ levels. In Inner Mongolia steppes, increasing the $\mathrm{N}$ supply shifted plant community composition from grass-forb codominance (primarily Stipa krylovii and Artemisia frigida, respectively) to exclusive dominance by grass, with associated declines in overall species richness. Reduced abundance of forbs was linked to soil acidification that increased mobilization of soil $\mathrm{Mn}$, with a 10 -fold greater accumulation of $\mathrm{Mn}$ in forbs than in grasses. The enhanced accumulation of $\mathrm{Mn}$ in forbs was correlated with reduced photosynthetic rates and growth, and is consistent with the loss of forb species. Differential accumulation of Mn between forbs and grasses can be linked to fundamental differences between dicots and monocots in the biochemical pathways regulating metal transport. These findings provide a mechanistic explanation for $\mathrm{N}$-induced species loss in temperate grasslands by linking metal mobilization in soil to differential metal acquisition and impacts on key functional groups in these ecosystems.
\end{abstract}

Key words: Artemisia frigida; forbs and grasses; Inner Mongolia, China; manganese mobilization and acquisition; nitrogen deposition; photosynthesis; soil acidification; species richness; Stipa krylovii; temperate steppe.

\section{INTRODUCTION}

There has been a dramatic increase in atmospheric $\mathrm{N}$ deposition due to fossil fuel combustion and the use of $\mathrm{N}$ fertilizers in the past century (Clark and Tilman 2008, Galloway et al. 2008), with 2010 values projected to increase $>1.5$-fold by 2030 (Bodirsky et al. 2014). This increase in $\mathrm{N}$ deposition is altering $\mathrm{N}$ cycling and the productivity and biodiversity of

Manuscript received 24 December 2014; accepted 26 June 2015. Corresponding Editor: S. D. frey

${ }^{13}$ E-mail: whzhang@ibcas.ac.cn terrestrial ecosystems globally (Galloway et al. 2008, Bobbink et al. 2010). In grassland ecosystems in particular, long-term $\mathrm{N}$ deposition has resulted in significant reductions in plant species richness and altered ecosystem function (Stevens et al. 2004, Clark et al. 2007, Harpole and Tilman 2007, Clark and Tilman 2008, Bobbink et al. 2010, Dupre et al. 2010, Fang et al. 2012, Isbell et al. 2013). Several mechanisms have been proposed to explain plant species loss with increased $\mathrm{N}$ deposition, but their relative importance is generally unknown (Suding et al. 2005, Clark et al. 2007, Harpole and Tilman 2007, Hautier et al. 2009, Borer et al. 2014). Competitive exclusion resulting from 
competition for resources, particularly for light, space, and soil resources, is often invoked as a cause of decline in species richness (Grime 1973, Hautier et al. 2009, Reich 2009, Borer et al. 2014). High levels of $\mathrm{N}$ deposition can also acidify the soil and potentially release phytotoxic metal ions including aluminum $\left(\mathrm{Al}^{3+}\right)$, manganese $\left(\mathrm{Mn}^{2+}\right)$, and iron $\left(\mathrm{Fe}^{3+}\right.$; van Breemen et al. 1982, Roem and Berendse 2000, Horswill et al. 2008). The metal toxicity mechanism is thought to explain overall species loss in grasslands (Grime 1963, Stevens et al. 2006, Bowman et al. 2008), but this mechanism's role in the commonly observed shift in grass-forb ratios that accompany biodiversity loss remains unresolved.

The semiarid grassland in Inner Mongolia (northern China) is an integral part of the Eurasian steppe, with high biodiversity and important ecological and agricultural functions (Kang et al. 2007). Nitrogen deposition rates have increased substantially in China over the past two decades (Liu et al. 2013), reaching the current rate of $16 \mathrm{~kg} \cdot \mathrm{ha}^{-1} \cdot \mathrm{yr}^{-1}$ in the region (Zhang et al. 2008), with clear evidence showing the tight connection between chronic $\mathrm{N}$ deposition and declines in species richness in temperate steppe ecosystems (Bai et al. 2010, Song et al. 2011, Fang et al. 2012, Lan and Bai 2012). Several studies have reported that reductions in species richness of grasslands by $\mathrm{N}$ deposition were due to greater losses of forbs than grasses (Stevens et al. 2006, Fang et al. 2012, Ceulemans et al. 2013). The temperate steppe in Inner Mongolia is codominated by the perennial grass Stipa krylovii and the perennial forb Artemisia frigida (Hou 1982, Fang et al. 2012), with typically low availability of iron (Fe) and manganese (Mn) for plants owing to high soil $\mathrm{pH}$ and high redox potential (Xiong and Li 1987). As with grasslands in Europe (Stevens et al. 2004, Ceulemans et al. 2013), $\mathrm{N}$ deposition acidifies the soils of temperate steppes (Fang et al. 2012, Lan and Bai 2012), resulting in the mobilization of a number of metal ions. Excessive foliar accumulation of these metals can be phytotoxic. Importantly, dicots and monocots differ in their mechanisms of metal acquisition (Marschner 1995, Curie and Briat 2003), suggesting that increases in soil $\mathrm{Mn}^{2+}$ and $\mathrm{Fe}^{3+}$ may be linked to the reduction in dicot forbs that constitute the majority of total plant richness in grasslands. Yet, this mechanism of differential accumulation of phytotoxic metals by forbs and grasses has not been directly tested. In the present study, we evaluated the roles of soil-mediated mobilization of metals and accumulation of metals by grasses and forbs in the plant species loss induced by long-term $\mathrm{N}$ addition in a temperate steppe of northern China.

\section{Methods}

We combined field work in the temperate steppe of Inner Mongolia with more controlled experiments in a greenhouse. The field work was carried out in Duolun County $\left(42^{\circ} 02^{\prime} \mathrm{N}, 116^{\circ} 17^{\prime} \mathrm{E} ; 1324 \mathrm{~m}\right.$ above sea level), Inner Mongolia, China. The area is of temperate climatic zone with mean annual temperature and precipitation of $2.1^{\circ} \mathrm{C}$ and $382.2 \mathrm{~mm}$ (which occurs predominantly in summer), respectively. Soils are Haplic Calcisols according to ISSS Working Group RB (1998). The soil is composed of (mean \pm standard error) $62.7 \% \pm 0.04 \%$ sand, $20.3 \% \pm 0.01 \%$ silt, and $16.9 \% \pm 0.01 \%$ clay, and mean soil bulk density and $\mathrm{pH}$ is $1.3 \mathrm{~g} / \mathrm{cm}^{3}$ and 6.8 , respectively. Ambient $\mathrm{N}$ deposition at the site is estimated to be $1.6 \mathrm{~g} \mathrm{~N} \cdot \mathrm{m}^{-2} \cdot \mathrm{yr}^{-1}$ (Zhang et al. 2008), and soil $\mathrm{N}$ mineralization rates in this area under ambient conditions are $-0.04-0.52 \mu \mathrm{g}$ $\mathrm{N} / \mathrm{g}$ soil during the $\sim 100-\mathrm{d}$ growing season (Zhang et al. 2012). Vegetation is a typical steppe community, mainly dominated by perennial species including $S$. krylovii, A. frigida, Potentilla acaulis, P. tanacetifolia, Dianthus chinensis, Heteropappus altaicus, Cleistogenes squarrosa, Allium bidentatum, Leymus chinensis, Carex korshinskyi, Melilotoides ruthenica, and Agropyron cristatum (Hou 1982).

\section{Field study design}

The $\mathrm{N}$ amendment experiment was initiated in 2003 after exclusion of livestock grazing. Sixty-four plots (each $15 \times 10 \mathrm{~m}$ ) separated by $4 \mathrm{~m}$ wide buffer strips were established in an $8 \times 8$ Latin square experimental design. There were eight levels of $\mathrm{N}$ (urea) addition $\left(0,1,2,4,8,16,32,64 \mathrm{~g} \mathrm{~N} \cdot \mathrm{m}^{-2} \cdot \mathrm{yr}^{-1}\right)$, with eight replicates per $\mathrm{N}$ treatment. The $\mathrm{N}$-addition rates used in our study were comparable to those used in other $\mathrm{N}$-addition experiments in grassland ecosystems (Bai et al. 2010, Dickson and Forster 2011). Alternative rows were mowed annually to simulate grazing, leading to four mowing and four non-mowing replicates per $\mathrm{N}$ treatment.

Urea is a widely used $\mathrm{N}$ fertilizer in China. The applied urea is rapidly hydrolyzed to ammonia/ammonium by urease in soils, and ammonium is further converted into nitrate by nitrification, leading to an increase in inorganic $\mathrm{N}$ in soils. Previous results showed that application of urea led to a significant increase in soil nitrate concentrations in this steppe (Fang et al. 2012). Therefore, the use of urea in our $\mathrm{N}$ addition experiments can simulate the natural $\mathrm{N}$ deposition. Urea $(\mathrm{N}, 46 \%)$ was applied annually in July when maximal precipitation occurs. Annual mowing to $2 \mathrm{~cm}$ height was conducted every August starting in 2005. In August 2012, we collected soil and plant samples from 48 plots representing six of the $\mathrm{N}$ addition $\times$ mowing treatments $\left(0,2,4,8,16\right.$, and $\left.32 \mathrm{~g} \mathrm{~N} \cdot \mathrm{m}^{-2} \cdot \mathrm{yr}^{-1}\right)$.

Species richness and aboveground plant biomass were measured in each plot in mid-August annually using a $1 \times 1 \mathrm{~m}$ quadrat as described by Fang et al. (2012). Briefly, the quadrat was randomly placed in each plot that was not overlapped spatially among years and at 
least $1 \mathrm{~m}$ inside the border of plots to avoid edge effects. Individual plants were harvested by clipping the entire aboveground part of each plant to determine their aboveground biomass. After determination of aboveground plant biomass, leaves of grasses and forbs from each plot were subsampled, dried at $75^{\circ} \mathrm{C}$, and digested with a mixture of nitric acid and hydrogen peroxide. The digested samples were used to determine manganese and iron concentrations by inductively coupled plasma optical emission spectrometry (ICP-OES; ICAP6300; Thermo Electric, West Chester, Pennsylvania, USA).

Photosynthetic rates of the two dominant species A. frigida and $S$. krylovii in plots with different $\mathrm{N}$ addition rates were measured on sunny days between 08:30 and 12:30 in August 2012 with a LI-6400 XT portable photosynthesis system equipped with a LED leaf cuvette (Li-Cor, Lincoln, Nebraska, USA). Artificial illumination was applied to the leaves in the chamber from a red-blue 6400-02B LED light source (Li-Cor) attached to the sensor head with continuous light (1000 $\mu \mathrm{mol} \cdot \mathrm{m}^{-2} \cdot \mathrm{s}^{-1}$ photosynthetic photon flux density) and ambient $\mathrm{CO}_{2}$ concentration of $\sim 400 \mu \mathrm{mol} \mathrm{CO}_{2} /$ mol (Niu et al. 2005). At least two individual S. krylovii and $A$. fridiga plants in each plot were selected for measuring photosynthetic rates.

Soil samples from three depths (0-10, 10-20, 20$30 \mathrm{~cm}$ ) in each plot were collected using a $10 \mathrm{~cm}$ diameter soil core in August 2012. Soil samples were sieved and air-dried for determination of soil $\mathrm{pH}$ and mineral elements. For soil pH, $6 \mathrm{~g}$ of air-dried soil was incubated in $15 \mathrm{~mL} \mathrm{CO}$-free deionized water for $1 \mathrm{~h}$ prior to $\mathrm{pH}$ measurement (Hanna PH211; Hanna Instruments, Padova, Italy). Exchangeable concentrations of $\mathrm{Mn}^{2+}$ and $\mathrm{Fe}^{3+}$ in the soil were estimated from $25 \mathrm{~g}$ soil extracted for $2 \mathrm{~h}$ with $50 \mathrm{~mL}$ extracting agent composed of $5 \mathrm{mmol} / \mathrm{L}$ diethylenetriaminepentaacetic acid (DTPA), $10 \mathrm{mmol} / \mathrm{L} \mathrm{CaCl}_{2}$, and $0.1 \mathrm{~mol} / \mathrm{L}$ triethanolamine (TEA) at a $\mathrm{pH}$ of 7.3 (Lindsay and Norvell 1978). To extract soil exchangeable $\mathrm{Al}^{3+}, 10 \mathrm{~g}$ air-dried soil was incubated in $50 \mathrm{~mL}$ of the $0.1 \mathrm{~mol} / \mathrm{L}$ $\mathrm{BaCl}_{2}$ ( $\mathrm{pH} 5.3$ ) for $30 \mathrm{~min}$, and the filtered extraction solution was analyzed for Al (Bowman et al. 2008). The metal concentrations $\left(\mathrm{Mn}^{2+}, \mathrm{Fe}^{3+}\right.$, and $\left.\mathrm{Al}^{3+}\right)$ of the extracted solutions were measured by ICP-OES.

\section{Greenhouse experiment}

To determine if the two dominant species, A. frigida and S. krylovii, differ in their sensitivity to soil $\mathrm{Mn}^{2+}$ concentrations, we collected seeds from control plots and planted them in pots $(20 \mathrm{~cm}$ diameter $)$ filled with vermiculite and irrigated with one-eighth strength Hoagland solution under controlled growth conditions. After growth for 5 weeks, five $A$. frigida and $S$. krylovii seedlings in each pot were treated with one-eighth strength Hoagland solution supplemented with varying concentrations of $\mathrm{MnCl}_{2}(0,50,100,250,500,1000 \mu \mathrm{mol} / \mathrm{L})$ for $10 \mathrm{~d}$. Thereafter biomass, foliar concentrations of $\mathrm{Mn}$ and $\mathrm{Fe}$, and photosynthetic rates were determined as described previously. At least two S. krylovii and $A$. frigida seedlings in each pot were used to measure photosynthetic rates with five replicates for each $\mathrm{MnCl}_{2}$ treatment, and each replicate contained five $A$. frigida and $S$. krylovii seedlings. The $\mathrm{MnCl}_{2}$ concentrations used in our study were similar to those commonly used in studies of Mn toxicity (Millaleo et al. 2013).

\section{Statistical analysis}

Because $\mathrm{N}$ addition led to a similar reduction in species richness among mowed and non-mowed plots (Appendix S1: Fig. S1), the two treatments were pooled in all subsequent analyses. In addition, a significant reduction in species richness by $\mathrm{N}$ addition was observed in 2007, and that effect has lasted throughout the experimental period with interannual variation (Appendix S1: Fig. S2). We therefore focused our analyses on data between 2007 and 2012 and conducted analyses on mean plant richness (total, grass and forb) and biomass (total, grass, forb, S. krylovii, and $A$. frigida) across this period. One-way ANOVA (Duncan's test) was used to evaluate plant biomass, species richness, photosynthesis, and soil and foliar metal concentrations under varying $\mathrm{N}$ addition rates for the field experiment and under varying $\mathrm{MnCl}_{2}$ concentrations in the greenhouse experiment (SPSS 16.0; SPSS, Chicago, Illinois, USA). Treatment means were compared by least significant difference (LSD) post hoc tests, with significance set at $P<0.05$. Regression analyses were used to assess the correlation between foliar $\mathrm{Mn}, \mathrm{Fe}$, and photosynthetic rates (Pn) with $\mathrm{N}$ additions and greenhouse $\mathrm{MnCl}_{2}$ treatments. All analyses were conducted in SPSS 16.0.

\section{RESUlts}

\section{Effects of $N$ addition on aboveground plant biomass and plant species richness}

Long-term $\mathrm{N}$ addition significantly enhanced overall aboveground plant biomass (Fig. 1a), with the magnitude of the increase positively dependent on $\mathrm{N}$ addition rates. However, the increase plateaued at the $\mathrm{N}$-addition rate of $8 \mathrm{~g} \mathrm{~N} \cdot \mathrm{ha}^{-1} \cdot \mathrm{yr}^{-1}$ (Fig. 1a). We further examined the effect of $\mathrm{N}$ addition on biomass of grasses and forbs and found that $\mathrm{N}$ addition significantly enhanced the biomass of grasses, while the biomass of forbs was significantly reduced by $\mathrm{N}$ (Fig. 1b,c). As the steppe community is co-dominated by the forb $A$. frigida and grass $S$. krylovii, the effects of $\mathrm{N}$ addition on the biomass of the two species were also evaluated. Similar to the biomass of forbs and grasses, $\mathrm{N}$ addition led to a significant reduction and increase in the biomass of A. frigida and S. krylovii, respectively (Fig. 1b,c), suggesting that the changes in 

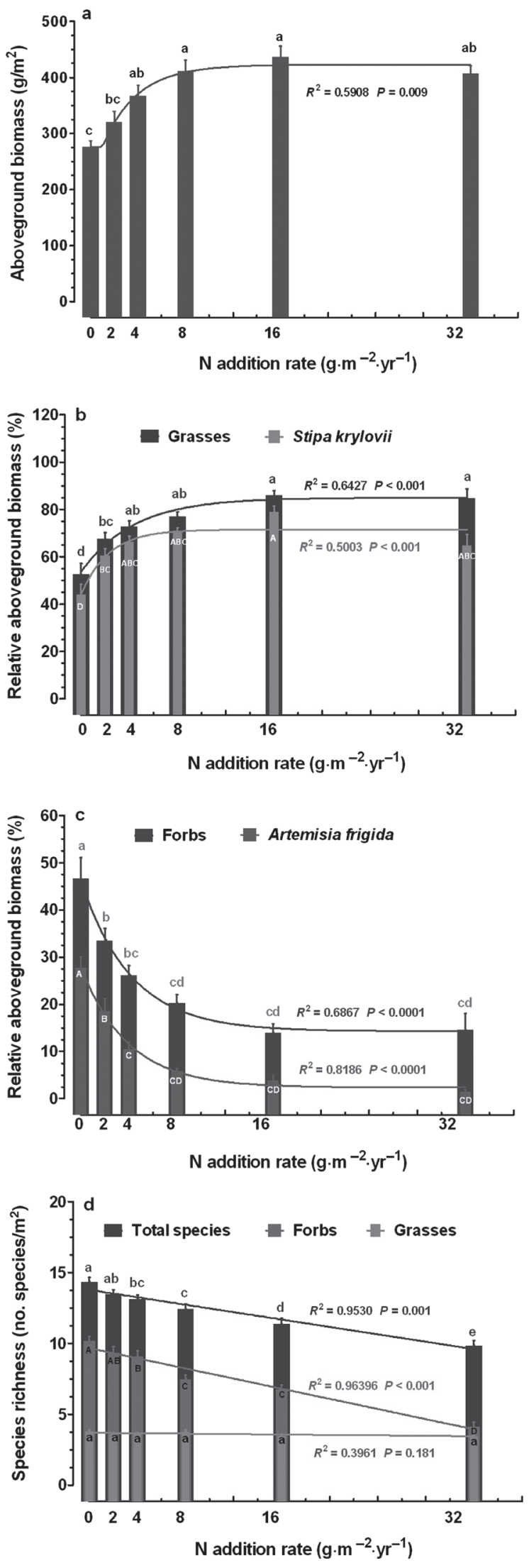

FIG. 1. Nitrogen addition has different effects on aboveground biomass and species richness of grasses and forbs. (a) Nitrogen addition enhanced overall aboveground biomass as well as (b) aboveground biomass of grasses and Stipa krylovii, but (c) N addition reduced aboveground biomass of forbs and Artemisia frigida. (d) Nitrogen addition reduced the overall species richness, and species richness of forbs, but it had no effect on species richness of grasses. Species richness and aboveground biomass were determined in $1-\mathrm{m}^{2}$ quadrats and pooled over a 6 -yr period (2007-2012). Data are means $\pm \operatorname{SE}(n=8)$. Relative aboveground biomass of grasses $\left(R^{2}=0.6427, P<0.001\right.$; relationships significant at $P<0.05)$ and $S$. krylovii $\left(R^{2}=0.5003\right.$, $P<0.001$ ) was positively correlated with (b) $\mathrm{N}$-addition rate and relative aboveground biomass of forbs $\left(R^{2}=0.6867, P<0.0001\right)$ and (c) A. frigida $\left(R^{2}=0.8186, P<0.0001\right)$ was negatively correlated with $\mathrm{N}$-addition rate. The overall species richness $\left(R^{2}=0.9530, P=0.001\right)$ and species richness of forbs $\left(R^{2}=0.96396, P<0.001\right)$ were negatively correlated with $\mathrm{N}$ addition rates, while there was no significant correlation between species richness of grasses and $\mathrm{N}$-addition rates $\left(R^{2}=0.3961\right.$, $P=0.181)$. Different letters above the bars represent significant differences among different $\mathrm{N}$-addition rates at $P<0.05$.

the biomass of the community are driven primarily by these two co-dominant species.

In contrast to biomass responses, there was a linear reduction in total species richness with increasing $\mathrm{N}$ addition rate (Fig. 1d). Further, $\mathrm{N}$ addition also had different effects on species richness of forbs and grasses, such that $\mathrm{N}$ addition at greater than $4 \mathrm{~g} \cdot \mathrm{m}^{-2} \cdot \mathrm{yr}^{-1}$ significantly reduced forb species richness, while grass species richness was relatively constant across all $\mathrm{N}$-addition rates (Fig. 1d). Thus, the reduction in plant species richness by $\mathrm{N}$ addition was driven entirely by the loss of forb species. The linear negative correlation between $\mathrm{N}$ addition rate and forb species richness indicates that for every $\sim 5 \mathrm{~g} \cdot \mathrm{m}^{-2} \cdot \mathrm{yr}^{-1}$ increase in the rate of added $\mathrm{N}$ to simulate $\mathrm{N}$ deposition in Inner Mongolia steppe, an additional forb species per square meter is lost.

\section{Effects of $N$ addition on photosynthetic rates}

To determine if the differential effects of $\mathrm{N}$ addition on plant biomass and species richness of forb and grass species can be related to their photosynthetic responses, photosynthetic rates of the two dominant species, A. frigida and S. krylovii, under varying $\mathrm{N}$ addition rates were determined in the field. Photosynthetic rates of $A$. frigida were significantly reduced by $\mathrm{N}$ addition $(P<0.0001$, Fig. 2$)$, whereas $\mathrm{N}$ addition up to $32 \mathrm{~g} \cdot \mathrm{m}^{-2} \cdot \mathrm{yr}^{-1}$ had no impact on photosynthetic rates of S. krylovii (Fig. 2).

\section{Effects of $N$ addition on foliar metal concentrations of plants}

The differential effects of $\mathrm{N}$ addition on photosynthetic rates of $A$. frigida and $S$. krylovii prompted us to test whether $\mathrm{N}$ addition led to changes in foliar accumulation of metals that can impact the photosynthetic processes. 


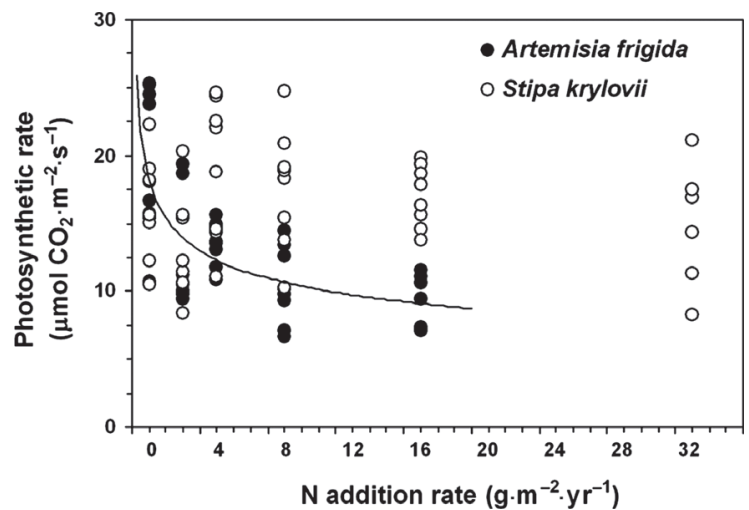

FIG. 2. Effects of $\mathrm{N}$-addition on photosynthesis of $S$. krylovii and $A$. frigida in the field. Photosynthetic rates of $A$. frigida were significantly $(P<0.05)$ and negatively correlated with $\mathrm{N}$-addition rates $\left(R^{2}=0.4796, P<0.001\right)$. Data were collected from plots treated with different levels of $\mathrm{N}$ addition for $9 \mathrm{yr}$.

We examined the effect of $\mathrm{N}$ addition on foliar concentrations of several metals in the two co-dominant species in the field experiment. Nitrogen addition caused linear

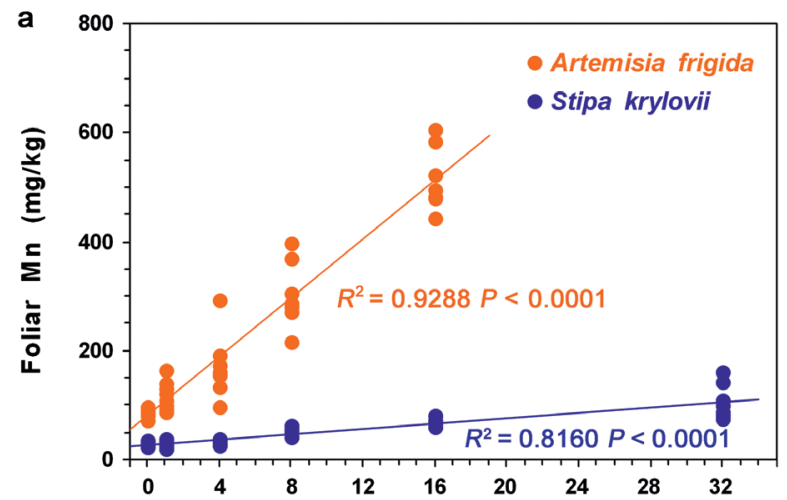

b

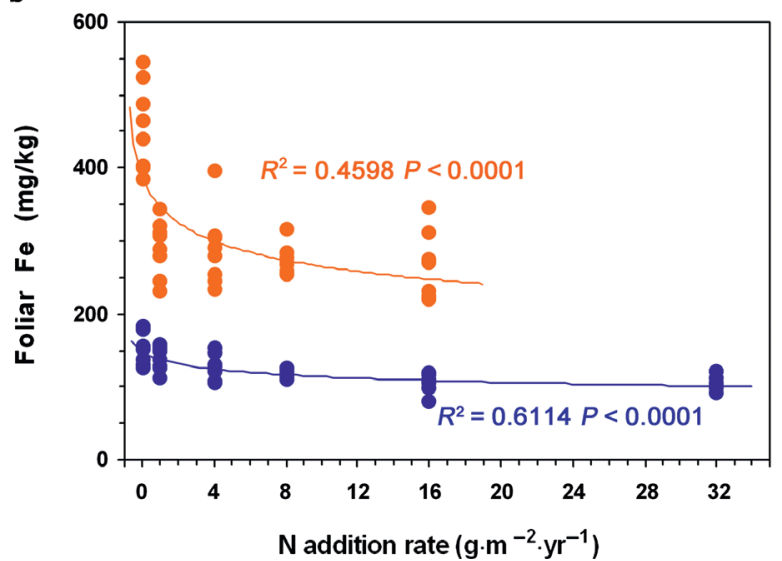

increases in foliar Mn concentrations for both $A$. frigida $(P<0.0001)$ and $S$. krylovii $(P<0.0001)$, but the increase in A. frigida was much greater than in $S$. krylovii (Fig. 3a). In contrast to foliar $\mathrm{Mn}$ concentration, $\mathrm{N}$ addition reduced foliar Fe concentrations in A. frigida $(P<0.0001)$ and S. krylovii $(P<0.0001)$, again with reductions much greater in A. frigida than in S. krylovii (Fig. 3b). To verify whether $\mathrm{N}$ addition has similar effects on accumulation of $\mathrm{Mn}$ and $\mathrm{Fe}$ by forbs and grasses, foliar $\mathrm{Mn}$ and $\mathrm{Fe}$ concentrations in other forbs and grasses under different $\mathrm{N}$ addition rates were also measured. Similar patterns of accumulation of $\mathrm{Mn}$ and $\mathrm{Fe}$ were found more generally for grass and forb species in the $\mathrm{N}$-amended plots (Fig. 3c,d), suggesting that the greater Mn accumulation and reduction of $\mathrm{Fe}$ accumulation in $A$. frigida than in S. krylovii are representative of differences in $\mathrm{Mn}$ and $\mathrm{Fe}$ acquisition between forbs and grasses generally.

\section{Effects of $N$ addition on soil $p H$ and mineral ion concentrations}

To further explore $\mathrm{N}$ addition-induced accumulation of $\mathrm{Mn}$ and suppression of $\mathrm{Fe}$ acquisition, the effects

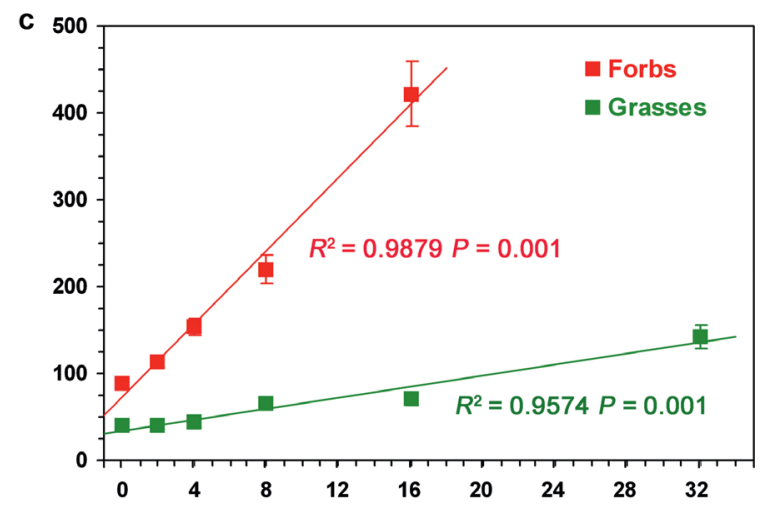

d

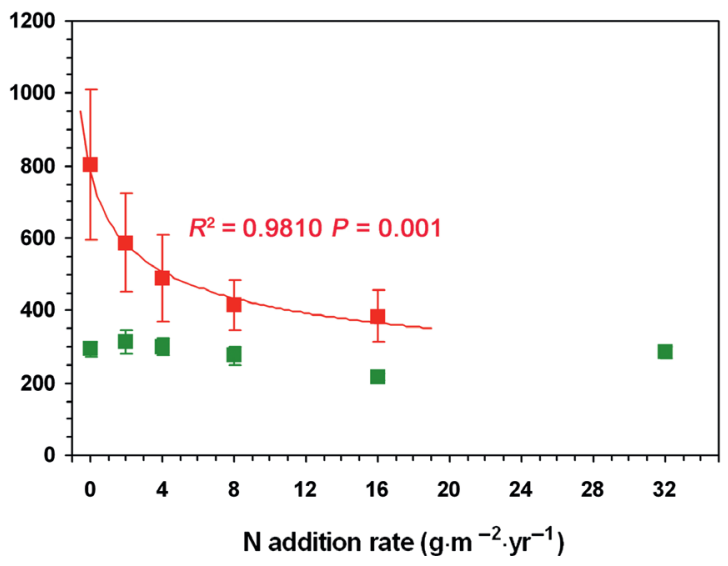

FIG. 3. Nitrogen addition effects on the accumulation of $\mathrm{Mn}$ and $\mathrm{Fe}$ in forb and grass species based on foliar $\mathrm{Mn}$ and Fe concentrations in (a, b) A. frigida and S. krylovii in plots treated with different N-addition rates for 9 yr; (c, d) foliar Mn and Fe concentrations of six forbs (A. frigida, Potentilla acaulis, P. bifurca, P. tanacetifolia, Dianthus chinensis, Heteropappus altaicus) and four grass species (S. krylovii, Agropyron cristatum, Leymus chinensis, Cleistogenes squarrosa) were determined and averaged. Data represent means $\pm \operatorname{SE}(n=8)$. 
of $\mathrm{N}$ addition on soil properties were studied. Soil $\mathrm{pH}$ was reduced by $\mathrm{N}$ addition in a dose-dependent manner (Fig. 4a), and the reduction was most evident at the shallowest soil depth (Appendix S1: Fig. S3). In addition, $\mathrm{N}$ addition led to linear increases in the concentrations of soil exchangeable manganese $\left(\mathrm{Mn}^{2+}\right)$, ferric iron $\left(\mathrm{Fe}^{3+}\right)$, and aluminum $\left(\mathrm{Al}^{3+}\right)$ in soils (Fig. 4b,c). These increases were most profound in the upper soil layer (Appendix S1: Fig. S4), while N addition had no effect on soil $\mathrm{NH}_{4}^{+}$concentrations (Fig. 4c).

\section{Effects of $\mathrm{MnCl}_{2}$ on growth and photosynthetic rates}

To evaluate differential accumulation of Mn between the forb and grass as a mechanism for the $\mathrm{N}$-induced loss of forb species, we conducted a greenhouse experiment with $A$. frigida and $S$. krylovii seedlings exposed to varying concentrations of $\mathrm{MnCl}_{2}$. Biomass of shoots and roots in $A$. frigida was significantly reduced by $\mathrm{MnCl}_{2}$, but the same treatment had no effect on the biomass of S. krylovii (Fig. 5a,b). Like the field results, addition of $\mathrm{MnCl}_{2}$ caused a much greater increase and decrease in foliar $\mathrm{Mn}$ and $\mathrm{Fe}$ concentrations in $A$. frigida than in $S$. krylovii (Fig. 5c,d). Furthermore, $\mathrm{MnCl}_{2}$ addition significantly reduced photosynthetic rates of $A$. frigida $(P<0.0001$, Fig. 5e), while the same treatment led to an increase in photosynthetic rates of $S$. krylovii $(P=0.002$, Fig. 5e).

\section{DisCUSSION}

Several mechanisms have been proposed to explain species loss induced by enhanced $\mathrm{N}$ deposition in grasslands, with most focused on the competitive exclusion of less common species (Suding et al. 2005, Clark et al. 2007, Harpole and Tilman 2007, Hautier et al. 2009). Here, we demonstrated that chronic $\mathrm{N}$ addition reduced richness of forbs and enhanced soil $\mathrm{Mn}^{2+}$ and $\mathrm{Fe}^{3+}$ concentrations due to soil acidification in an Inner Mongolia steppe. We further showed that forb species accumulated much greater amounts of $\mathrm{Mn}$ in their foliage compared to grasses across the $\mathrm{N}$-addition gradient. The accumulation of $\mathrm{Mn}$ and suppression of $\mathrm{Fe}$ acquisition by forb species were associated with reduced photosynthetic rates and growth. Combined, these results point to an alternative mechanism for the loss of forb species in the temperate steppes under conditions of high $\mathrm{N}$ deposition: differential sensitivity of grasses vs. forbs to $\mathrm{N}$-induced mobilization of soil $\mathrm{Mn}^{2+}$. This differential sensitivity is accounted for by intrinsic differences in the acquisition of $\mathrm{Mn}$ and $\mathrm{Fe}$ between dicots and monocots (Marschner 1995, Curie and Briat 2003). Indeed, our results showed that $\mathrm{N}$ inputs as low as $2 \mathrm{~g} \cdot \mathrm{m}^{-2} \cdot \mathrm{yr}^{-1}$ for nine years can significantly reduce aboveground biomass of forbs, particularly the dominant forb $A$.
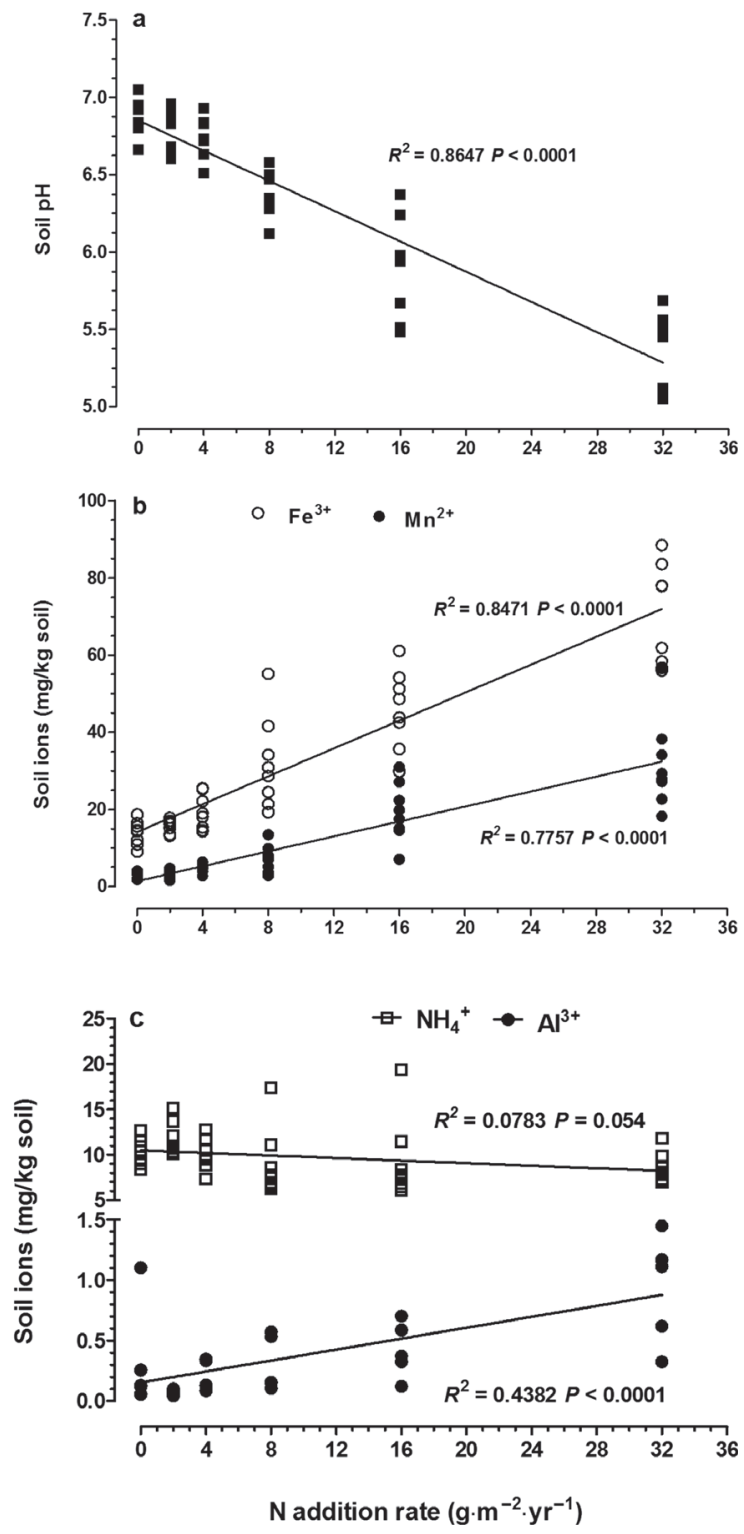

FIG. 4. Effects of $\mathrm{N}$ addition on (a) soil $\mathrm{pH}$, (b) $\mathrm{Mn}^{2+}$ and $\mathrm{Fe}^{3+}$ concentrations, and (c) $\mathrm{NH}_{4}^{+}$and $\mathrm{Al}^{3+}$ concentrations in the top soil layer $(0-10 \mathrm{~cm})$. Soil $\mathrm{pH}\left(R^{2}=0.8647, P<0.0001\right), \mathrm{Mn}^{2+}$ $\left(R^{2}=0.7757, P<0.0001\right), \mathrm{Fe}^{3+}\left(R^{2}=0.8471, P<0.0001\right)$, and $\mathrm{Al}^{3+}\left(R^{2}=0.4382, P<0.0001\right)$ concentrations in soil showed linear correlation with $\mathrm{N}$-addition rate.

frigida (Fig. 1b), inhibiting photosynthetic rates of this species by $40 \%$ (Fig. 2), and $4 \mathrm{~g} \cdot \mathrm{m}^{-2} \cdot \mathrm{yr}^{-1}$ of $\mathrm{N}$ addition can cause a significant reduction in forb species richness (Fig. 1d). Therefore, these findings provide support for a biochemical explanation for the widely observed loss of forb species under low to moderate levels of $\mathrm{N}$ deposition in grassland ecosystems (Stevens et al. 2006, Fang et al. 2012, Ceulemans et al. 2013) by linking soil-mediated metal mobilization, and root acquisition of metals by plants to impacts on leaf-level photosynthesis. 
This biochemical basis of differential Mn accumulation between forbs and grasses may explain the widely observed loss of forbs with increased $\mathrm{N}$ deposition in many grasslands (Stevens et al. 2006, Ceulemans et al. 2013). Increased light limitation with enhanced $\mathrm{N}$ deposition has previously been invoked as the primary mechanism driving species loss in a broad range of grasslands (Hautier et al. 2009, Borer et al. 2014). However, the mowing treatment did not alleviate $\mathrm{N}$-addition-induced species loss (Appendix S1: Fig. S1), suggesting that increased
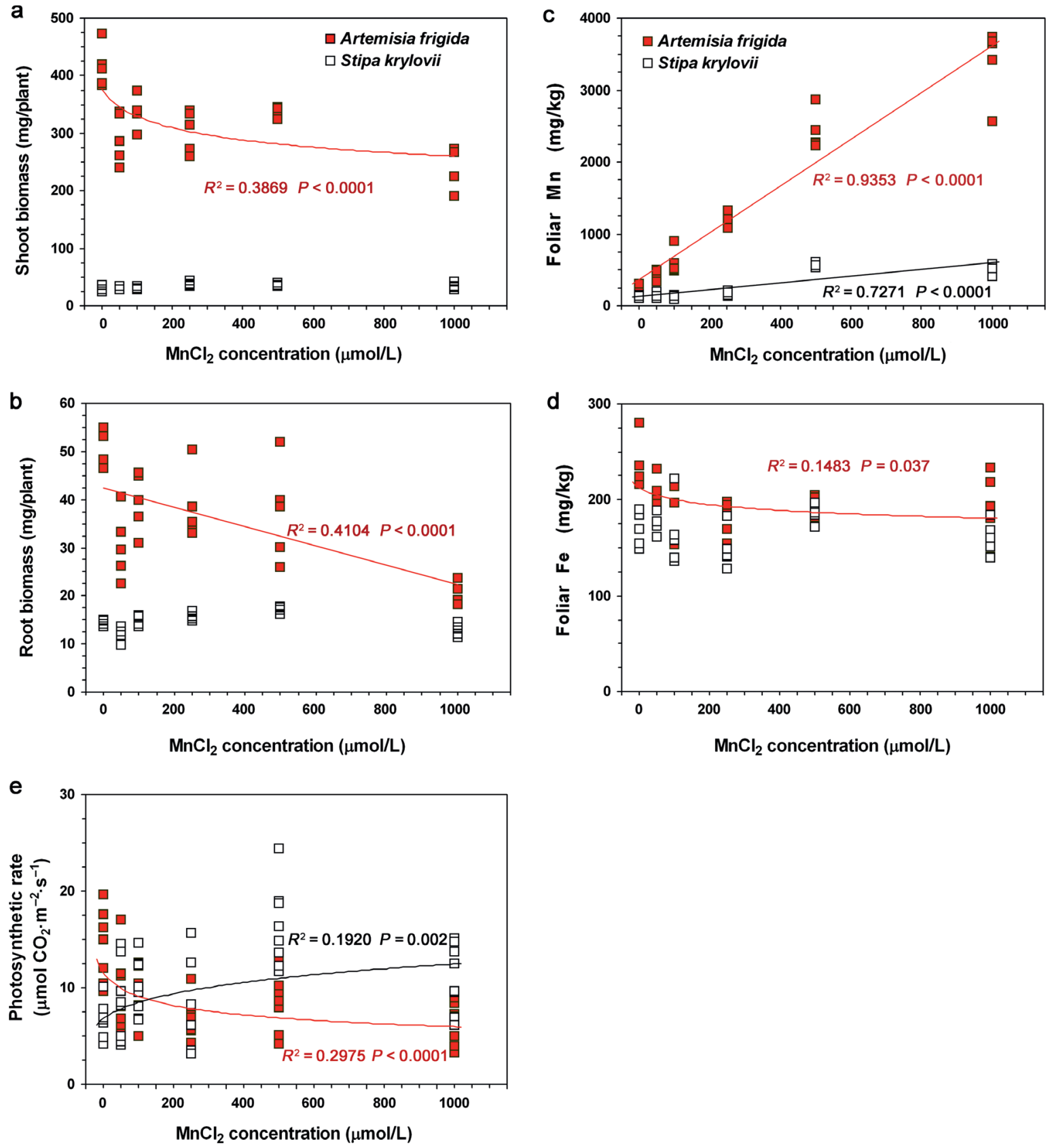

FIG. 5. A. frigida and S. krylovii seedlings exhibit differential sensitivity to $\mathrm{MnCl}_{2}$ treatments in the greenhouse. (a, b) Shoot and root biomass of $A$. frigida seedlings are negatively correlated with $\mathrm{MnCl}_{2}$ concentrations applied to the pots, while shoot and root biomass of $S$. krylovii seedlings are independent of the applied $\mathrm{MnCl}_{2}$ concentrations. (c, d) Foliar concentrations of $\mathrm{Mn}$ and $\mathrm{Fe}$ in $A$. frigida and $S$. krylovii seedlings treated with varying $\mathrm{MnCl}_{2}$ concentrations; effects of $\mathrm{MnCl}_{2}$ on photosynthetic rates of $A$. frigida and $S$. krylovii. (e) Biomass, foliar concentrations of $\mathrm{Mn}$ and $\mathrm{Fe}$, and photosynthetic rates of $A$. frigida and $S$. krylovii seedlings were measured after seedlings were treated with varying concentrations of $\mathrm{MnCl}_{2}$ for $10 \mathrm{~d}$. 
competition for light with $\mathrm{N}$ addition was not necessary for the loss of forb species in our system. Others have reported similar results, that decreases in plant biodiversity due to $\mathrm{N}$ addition can be independent of light intensity (Dickson and Forster 2011). Instead, we observed that $\mathrm{N}$ addition led to a sharp accumulation of $\mathrm{Mn}$ and suppression of photosynthetic rates in forb species, leading to a negative correlation between photosynthetic rates and foliar Mn concentration in A. frigida (Appendix S1: Fig. S5). These findings support an alternative plant growth form-based mechanism for species loss, particularly for ecosystems that experience acidification by chronic $\mathrm{N}$ deposition. Our findings may also have important implications for conservation of plant biodiversity in alkaline temperate grasslands. Significant soil acidification of temperate grasslands in northern China (reduction in soil $\mathrm{pH}$ by 0.63 units) has been reported over the past two decades due to anthropogenic activities (Yang et al. 2012). Based on the present study, $\mathrm{N}$ addition at $8 \mathrm{~g} \cdot \mathrm{m}^{-2} \cdot \mathrm{yr}^{-1}$ for nine years reduced soil $\mathrm{pH}$ by $\sim 0.6$ units, and this acidification can lead to an approximately fourfold increase in soil Mn concentrations (Appendix S1: Fig. S6). Therefore, even moderate soil acidification by $\mathrm{N}$ deposition may expose native grassland species to

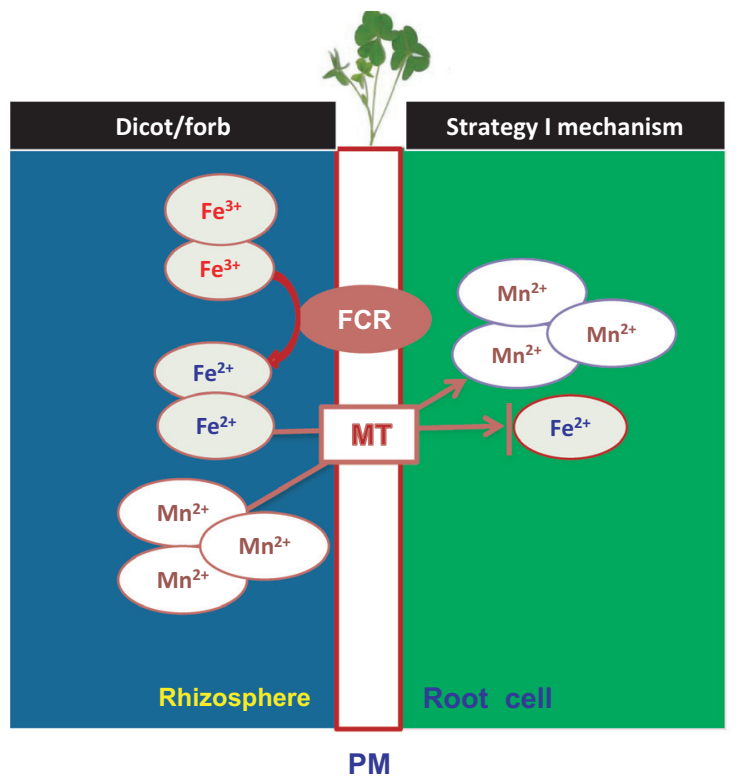

potential Mn toxicity, particularly for the species-rich forbs that more readily accumulate excessive $\mathrm{Mn}$.

In addition to competition for light, belowground competition for soil resources (Rajaniemi 2002) and mobilization of toxic metals such as aluminum (Roem and Berendse 2000, Bowman et al. 2008, Horswill et al. 2008, Stevens et al. 2009) have also been suggested to be involved in species richness declines with $\mathrm{N}$ deposition in acidic grasslands. Toxic $\mathrm{Al}^{3+}$ species are solubilized and may suppress root growth when soil $\mathrm{pH}$ is reduced to below 5 (Tyler 1996, Rengel and Zhang 2003). However, we found that the exchangeable $\mathrm{Al}^{3+}$ concentration in soils in our field experiment was relatively low (Appendix $\mathrm{S} 1$ : Fig. S6) and soil $\mathrm{pH}$ was $>5$ across the entire $\mathrm{N}$ gradient (Fig. 4a). Indeed, soil $\mathrm{Al}^{3+}$ concentrations were not significantly different between control and $\mathrm{N}$-added plots with $\mathrm{N}$ addition of less than $32 \mathrm{~g} \mathrm{~N} \cdot \mathrm{m}^{-2} \cdot \mathrm{yr}^{-1}$ (Fig. 4c). Finally, foliar $\mathrm{Al}$ concentrations in $A$. frigida were reduced by $\mathrm{N}$ additions, whereas foliar $\mathrm{Al}$ concentrations in $S$. krylovii were relatively constant across the $\mathrm{N}$ treatments (Appendix S1: Fig. S7). Together, these observations suggest that Al toxicity is unlikely to be involved in the loss of $A$. frigida. In addition to $\mathrm{Al}$ toxicity, ammonia toxicity has been suggested to be

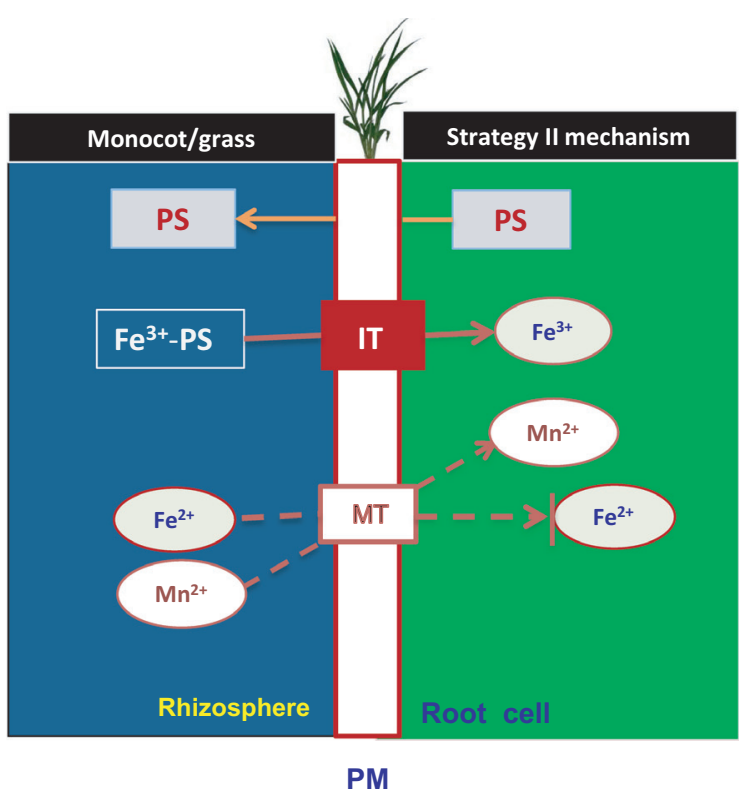

FIG. 6. Summary of the different mechanisms used by dicots (forbs) and monocots (grasses) in the acquisition of Fe and Mn with high rates of $\mathrm{N}$ addition. Acquisition of $\mathrm{Fe}$ by dicots is mediated by the reduction of $\mathrm{Fe}^{3+}$ to $\mathrm{Fe}^{2+}$ catalyzed by the ferric chelate reductase (FCR) in root cells, referred to as the Strategy I mechanism (Marschner 1995, Curie and Briat 2003). A metal transporter (MT) in the root cell membrane allowing for influx of both $\mathrm{Fe}^{2+}$ and $\mathrm{Mn}^{2+}$ into roots underlies their Fe and $\mathrm{Mn}$ acquisition. By contrast, monocot grasses acquire Fe from soil through a chelation-based mechanism, known as the Strategy II mechanism (Marschner 1995, Curie and Briat 2003). Monocot grasses exude phytosiderophore (PS) to form $\mathrm{Fe}^{3+}$-PS complex for subsequent uptake by an iron transporter (IT) in the root cell membrane. In addition to uptake of $\mathrm{Fe}^{3+}$, monocot grasses may also take up $\mathrm{Fe}^{2+}$ and $\mathrm{Mn}^{2+}$ as in dicots. But this transport system plays a minor role in the overall Fe acquisition in monocots. These differences in $\mathrm{Fe}$ acquisition systems between dicots and monocots may account for greater accumulation of $\mathrm{Mn}$ and consequent suppression of Fe acquisition under conditions of higher $\mathrm{Mn}^{2+}$ concentrations due to $\mathrm{N}$-addition-induced $\mathrm{Mn}$ mobilization. PM stands for plasma membrane. 
responsible for the reduction in species richness by $\mathrm{N}$ deposition (Kleijn et al. 2008, Zhang et al. 2014). Differences in $\mathrm{NH}_{4}^{+}$concentrations in the upper soil layers were not significant among plots treated with different rates of $\mathrm{N}$ addition (Fig. 4c), highlighting that $\mathrm{NH}_{4}^{+}$toxicity is not a major factor driving the loss of A. frigida under our experimental conditions.

\section{Differences in monocot and dicot biochemistry with respect to acquisition of metals}

The differences in accumulation of $\mathrm{Mn}$ and $\mathrm{Fe}$ between $A$. frigid and $S$. krylovii, or more generally between forbs and grasses, are likely caused by the intrinsic differences in acquisition of $\mathrm{Fe}$ and $\mathrm{Mn}$ between monocots and dicots. Dicot forbs acquire $\mathrm{Fe}^{2+}$ after reduction of soil $\mathrm{Fe}^{3+}$ to $\mathrm{Fe}^{2+}$ by ferric chelate reductases in roots; a metal transporter then mediates uptake of $\mathrm{Fe}^{2+}$ and $\mathrm{Mn}^{2+}$ into roots (Marschner 1995, Curie and Briat 2003), while Fe acquisition by monocot grasses involves exudation of phytosiderophores to form a $\mathrm{Fe}^{3+}$-phytosiderophores complex, and subsequent uptake of the complex into roots through a different transporter (Marschner 1995, Curie and Briat 2003). Monocot grasses possess a transporter similar to dicots, allowing uptake of $\mathrm{Fe}^{2+}$ and $\mathrm{Mn}^{2+}$ into roots, but this pathway plays a minor role in the overall Fe acquisition in these plants (Marschner 1995, Curie and Briat 2003). The mobilization of soil $\mathrm{Mn}^{2+}$ by $\mathrm{N}$ deposition renders higher foliar $\mathrm{Mn}$ concentrations than $\mathrm{Fe}$ because uptake of $\mathrm{Mn}^{2+}$ outcompetes $\mathrm{Fe}^{2+}$ uptake in forbs, while the mobilization of $\mathrm{Mn}^{2+}$ has a much smaller effect on $\mathrm{Fe}^{3+}$ uptake by grasses. Therefore, $\mathrm{N}$ addition has less effect on foliar Fe concentration in S. krylovii and other grasses than that in A. frigida and other forbs (Fig. 3), suggesting that fundamental differences in the biochemical pathways of $\mathrm{Fe}$ acquisition between dicots and monocot grasses underlie the differences in $\mathrm{Mn}$ accumulation between $A$. frigida and S. krylovii, and between forbs and grasses (Fig. 6). Our greenhouse experiment confirmed that $A$. frigida seedlings were more sensitive to increasing $\mathrm{Mn}^{2+}$ concentrations than S. krylovii (Fig. 5). In addition to markedly enhanced foliar $\mathrm{Mn}$ and reduced $\mathrm{Fe}$ concentrations in $A$. frigida, $\mathrm{N}$ addition also moderately increased foliar $\mathrm{Mg}$ and $\mathrm{K}$ concentrations and reduced foliar $\mathrm{Ca}$ concentrations in A. frigida (Appendix $\mathrm{S} 1$ : Fig. S7), thus discounting the possibility that the enhanced foliar $\mathrm{Mn}$ concentrations in $A$. frigida by $\mathrm{N}$ addition results from concentrating effect due to inhibition of plant growth. Instead, these results suggest an involvement of a metal-specific acquisition mechanism in the increased foliar Mn concentrations.

In summary, we observed that $\mathrm{N}$ deposition reduced richness of forb species and mobilized soil $\mathrm{Mn}^{2+}$ due to soil acidification in a temperate steppe. We further showed that $\mathrm{N}$ addition led to a sharp accumulation of $\mathrm{Mn}$ and a concurrent suppression of photosynthetic rates in forb species. These findings support a novel and alternative mechanism for $\mathrm{N}$-deposition-induced species loss, particularly for ecosystems that experience acidification and the release of potentially toxic metals. By linking soil-mediated processes to nutrient acquisition and photosynthesis in plants, our findings provide a biochemical explanation potentially responsible for N-depositioninduced loss of forb species in vast areas of the Eurasian steppe and potentially other grassland systems experiencing N-deposition-induced acidification.

\section{ACKNOWLEDGMENTS}

We thank the staff at the Duolun Restoration Ecology Research Station, Institute of Botany, Chinese Academy of Sciences, for their help in maintaining the field facilities and collecting the canopy data. This work was supported by the Natural Science Foundation of China (31130008; 31272234; 31430016; 41320104002) and National Basic Research Program of China (2010CB833502). Q. Tian, N. Liu, and W. Bai all contributed equally to this study.

\section{Literature Cited}

Bai, Y., J. Wu, C. M. Clark, S. Naeem, Q. Pan, J. Huang, L. Zhang, and X. Han. 2010. Tradeoffs and thresholds in the effects of nitrogen addition on biodiversity and ecosystem functioning: evidence from Inner Mongolia grasslands. Global Change Biology 16:358-372.

Bobbink, R., et al. 2010. Global assessment of nitrogen deposition effects on terrestrial plant diversity: a synthesis. Ecological Applications 20:30-59.

Bodirsky, B. L., et al. 2014. Reactive nitrogen requirements to feed the world in 2050 and potential to mitigate nitrogen pollution. Nature Communications 5:3858.

Borer, E. T., et al. 2014. Herbivores and nutrients control grassland plant diversity via light limitation. Nature 508:517-521.

Bowman, W. D., C. Cleveland, L. Halada, J. Hreško, and J. S. Baron. 2008. Negative impact of nitrogen deposition on soil buffering capacity. Nature Geoscience 1:767-770.

van Breemen, N., P. A. Burrough, E. J. Velthorst, H. F. Van Dobben, T. De Wit, T. B. Ridder, and H. F. R. Reijnders. 1982. Soil acidification from atmospheric ammonium sulphate in forest canopy throughfall. Nature 299:548-550.

Ceulemans, T., R. Merckx, M. Hens, and O. Honnay. 2013. Plant species loss from European semi-natural grasslands following nutrient enrichment - is it nitrogen or is it phosphorus? Global Ecology and Biogeography 22:73-82.

Clark, C. M., and D. Tilman. 2008. Loss of plant species after chronic low-level nitrogen deposition to prairie grasslands. Nature 451:712-715.

Clark, C. M., E. E. Cleland, S. L. Collins, J. E. Fargione, L. Gough, S. C. Pennings, K. N. Sudding, and J. B. Grace. 2007. Environmental and plant community determinants of species loss following nitrogen enrichment. Ecology Letters 10:596-607.

Curie, C., and J. F. Briat. 2003. Iron transport and signaling in plants. Annual Review of Plant Biology 54:183-206.

Dickson, T. L., and B. L. Forster. 2011. Fertilization decreases plant biodiversity even when light is not limiting. Ecology Letters 14:380-388.

Dupre, C., et al. 2010. Changes in species richness and composition in European acidic grasslands over the past 70 years: the contribution of cumulative atmospheric nitrogen deposition. Global Change Biology 16:344-357. 
Fang, Y., F. Xun, W. Bai, W. Zhang, and L. Li. 2012. Long-term nitrogen addition leads to loss of species richness due to litter accumulation and soil acidification. PLoS ONE 7:e47369.

Galloway, J. N., A. R. Townsend, J. W. Erisman, M. Bekunda, Z. Cai, J. R. Freney, L. A. Martinelli, S. P. Seitzinger, and M. A. Sutton. 2008. Transformation of the nitrogen cycle: recent trends, questions, and potential solutions. Science 320:889-892.

Grime, J. M. 1963. An ecological investigation at a junction between two plant communities in Coombsdale on the Derbyshire Limestone. Journal of Ecology 51:391-402.

Grime, J. M. 1973. Competitive exclusion in herbaceous vegetation. Nature 242:344-347.

Harpole, W. S., and D. Tilman. 2007. Grassland species loss resulting from reduced niche dimension. Nature 446:791-793.

Hautier, Y., P. A. Niklaus, and A. A. Hector. 2009. Competition for light causes plant biodiversity loss after eutrophication. Science 324:636-638.

Horswill, P., O. O'Sullivan, G. K. Phoenix, J. A. Lee, and J. R. Leake. 2008. Base cation depletion, eutrophication and acidification of species-rich grasslands in response to long-term simulated nitrogen deposition. Environmental Pollution 155:336-349.

Hou, X. Y. 1982. Vegetation geography of China and chemical composition of dominant species. Science Press, Beijing, China.

Isbell, F., P. B. Reich, D. Tilman, S. E. Hobbie, S. Polasky, and S. Binder. 2013. Nutrient enrichment, biodiversity loss, and consequent declines in ecosystem productivity. Proceedings of National Academy of Sciences USA 110:11911-11916.

Kang, L., X. Han, Z. Zhang, and O. J. Sun. 2007. Grassland ecosystems in China: review of current knowledge and research advancement. Philosophical Transactions of the Royal Society B 362:997-1008.

Kleijn, D., R. M. Bekker, R. Bobbink, M. C. C. De Graaf, and J. G. M. Roelofs. 2008. In search for key biogeochemical factors affecting plant species persistence in heathland and acidic grasslands: a comparison of common and rare species. Journal of Applied Ecology 45:680-687.

Lan, Z. C., and Y. F. Bai. 2012. Testing mechanisms of Nenrichment induced species loss in a semiarid Inner Mongolia grassland: critical thresholds and implications for long-term ecosystem responses. Philosophical Transactions of the Royal Society B 367:3125-3134.

Lindsay, W. L., and W. A. Norvell. 1978. Development of a DTPA soil test for zinc, iron, manganese, and copper. Soil Science Society of American Journal 42:421-428.

Liu, X., et al. 2013. Enhanced nitrogen deposition over China. Nature 494:459-463.

Marschner, H. 1995. Mineral nutrition of higher plants. Academic Press, London, UK.

Millaleo, R., M. Reyes-Diaz, M. Alberdi, A. G. Ivanov, M. Krol, and N. P. Hüner. 2013. Excess manganese differentially inhibits photosystem I versus II in Arabidopsis thaliana. Journal of Experimental Botany 64:343-354.

Niu, S., Z. Yuan, Y. Zhang, W. Liu, L. Zhang, J. Huang, and S. Wan. 2005. Photosynthetic response of $\mathrm{C}_{3}$ and $\mathrm{C}_{4}$ species to seasonal water variability and competition. Journal of Experimental Botany 56:2867-2876.

Rajaniemi, T. K. 2002. Why does fertilization reduce plant species diversity? Testing three competition-based hypotheses. Journal of Ecology 90:316-324.

Reich, P. B. 2009. Elevated $\mathrm{CO}_{2}$ reduces losses of plant diversity caused by nitrogen deposition. Science 326:1399-1402.

Rengel, Z., and W. H. Zhang. 2003. Role of dynamics of intracellular calcium in aluminum toxicity syndrome. New Phytologist 159:295-314.

Roem, W. J., and F. Berendse. 2000. Soil acidity and nutrient supply ratio as possible factors determining changes in plant species diversity in grassland and heathland communities. Biological Conservation 92:151-161.

Song, L., X. Bao, X. Liu, Y. Zhang, P. Christie, A. Fangmeiser, and F. Zhang. 2011. Nitrogen enhancement enhances the dominance of grasses over forbs in a temperate steppe ecosystem. Biogeosciences 8:2341-2350.

Stevens, C. J., N. B. Dise, J. O. Mountford and D. J. Gowing. 2004. Impact of nitrogen deposition on the species richness of grasslands. Science 303:1876-1879.

Stevens, C. J., N. B. Dise, D. J. Gowing and J. O. Mountford. 2006. Loss of forb diversity in relation to nitrogen deposition in UK: regional trends and potential controls. Global Change Biology 12:1823-1833.

Stevens, C. J., N. B. Dise, and D. J. Gowing. 2009. Regional trends in soil acidification and exchangeable metal concentrations in relation to acid deposition rates. Environmental Pollution 157:313-319.

Suding, K. N., S. L. Collins, L. Gough, C. Clark, E. E. Cleland, K. L. Gross, D. G. Milchunas, and S. Pennings. 2005. Functional- and abundance-based mechanisms explain diversity loss due to $\mathrm{N}$ fertilization. Proceedings of National Academy of Science USA 102:4387-4392.

Tyler, G. 1996. Soil chemistry and plant distributions in rock habitats of southern Sweden. Nordic Journal of Botany 16:609-635.

Xiong, Y., and Q. K. Li. 1987. Soils of China. Science Press, Beijing, China.

Yang, Y., C. Ji, W. Ma, S. Wang, S. Wang, W. Han, A. Mohammat, D. Robinson, and P. Smith. 2012. Significant soil acidification across northern China's grasslands during 1980s-2000s. Global Change Biology 18:2292-2300.

Zhang, Y., L. Zheng, X. Liu, T. Jickells, J. N. Cape, K. Goulding, A. Fangmeier, and F. Zhang. 2008. Evidence for organic $\mathrm{N}$ deposition and its anthropogenic sources in China. Atmospheric Environment 42:1035-1041.

Zhang, X., Q. Wang, F. S. Gilliam, W. Bai, X. Han, and L. Li. 2012. Effect of nitrogen fertilization on net nitrogen mineralization in a grassland soil, northern China. Grass Forage Science 67:219-230.

Zhang, Y. H., X. Lü, F. Isbell, C. Stevens, X. Han, N. He, G. Zhang, Q. Yu, J. Huang, and X. Han. 2014. Rapid plant species loss at high rates and at low frequency of $\mathrm{N}$ addition in temperate steppe. Global Change Biology 20:3520-3529.

\section{SUPPORTING INFORMATION}

Additional supporting information may be found in the online version of this article at http://onlinelibrary.wiley.com/ doi/10.1890/15-0917.1/suppinfo 